\title{
Refaunation and the reinstatement of the seed-dispersal function in Gorongosa National Park
}

\author{
Marta Correia, ๆ Sérgio Timóteo, Susana Rodríguez-Echeverría, Alban Mazars-Simon, \\ and Ruben Heleno \\ Centre for Functional Ecology, Department of Life Sciences, University of Coimbra, Calçada Martim de Freitas, $3000-456$ Coimbra, \\ Portugal
}

\begin{abstract}
Large animals are important seed dispersers; however, they tend to be under a bigh extinction risk worldwide. There is compelling evidence that the global biodiversity crisis is leading to the deterioration of several ecosystem functions, but there is virtually no information on bow large-scale refaunation efforts can reinstate seed dispersal. We evaluated the effectiveness of a $62-\mathrm{km}^{2}$ wildife sanctuary, which was established to recover populations of large mammals in Gorongosa National Park (Mozambique), in restoring seed dispersal. We collected animal scats during the dry season of 2014 (June-August) along 5 transects inside and 5 transects outside the sanctuary fence ( $50 \mathrm{~km}$ total) with the same type of plant community, identified animal and plant species in the transects, and quantified the number of seeds in each scat. Based on these data, we built bipartite networks and calculated network and species-level descriptor values, and we compared data collected inside and outside the sanctuary. There were more scats (268 vs. 207) and more scats containing seeds (132 vs. 94) inside than outside the sanctuary. The number of mammal dispersers was also higher inside (17) than outside the sanctuary (11). Similarly, more seeds (2413 vs. 2124) and plant species (33 vs. 26) were dispersed inside than outside the sanctuary. Overall, the seed-dispersal network was less specialized (0.38 vs. 0.44) and there was a greater overlap (0.16 vs. 0.07) inside than outside the sanctuary. Both networks were significantly modular and antinested. The bigh number and richness of seeds dispersed inside the sanctuary was explained mostly by a bigher abundance of dispersers rather than by disperser identity. Our results suggest conservation efforts aimed at recovering populations of large mammals are belping to reestablish not only target mammal species but also their functional roles as seed dispersers in the ecosystem.
\end{abstract}

Keywords: Africa, defaunation, ecological restoration, frugivory, large herbivores, rewilding, wildlife sanctuary

Refaunación y Reestablecimiento de la Función de Dispersión de Semillas en el Parque Nacional Gorongosa

Resumen: Los animales de talla grande son importantes dispersores de semillas; sin embargo, tienden a estar bajo un riesgo alto de extinción a nivel mundial. Existen evidencias convincentes de que la crisis global de la biodiversidad está resultando en el deterioro de varias funciones ambientales, pero prácticamente no bay información sobre cómo los esfuerzos de refaunación a gran escala puede reestablecer la dispersión de semillas. Evaluamos la efectividad de un santuario de vida silvestre de $62 \mathrm{~km}^{2}$, el cual fue establecido para recuperar las poblaciones de grandes mamíferos en el Parque Nacional Gorongosa (Mozambique), en la restauración de la dispersión de semillas. Recolectamos beces de animales durante la época seca de 2014 (junio - agosto) a lo largo de cinco transectos adentro y cinco transectos afuera del cerco del santuario (50 km en total) con el mismo tipo de comunidad vegetal, identificamos las especies de animales y plantas en los transectos y cuantificamos el número de semillas en cada bez. Con base en estos datos, construimos redes bipartitas y calculamos los valores descriptivos a nivel de especie y de red, y comparamos los datos recolectados dentro y fuera del santuario. Hubo más heces (268 vs 207) y más beces con semillas (132 vs 94) adentro que afuera del santuario. El número de mamíferos dispersores también fue más alto (17) adentro que 
afuera del santuario (11). De manera similar, más semillas (2413 vs 2124) y especies de plantas (33 vs 26) fueron dispersadas adentro que afuera del santuario. En general, las red de dispersión de semillas estuvo menos especializada ( 0.38 vs 0.44 ) y bubo un traslape mayor ( 0.16 vs 0.07 ) adentro que afuera del santuario. Ambas redes fueron significativamente modulares y no anidadas. El número alto y la riqueza de semillas dispersadas adentro del santuario fue explicado en su mayoría por una abundancia más alta de dispersores que por la identidad de los dispersores. Nuestros resultados sugieren que los esfuerzos de conservación enfocados en la recuperación de poblaciones de grandes mamíferos están ayudando a restablecer no sólo a las especies alvo, sino también su papel funcional como dispersores de semillas en el ecosistema.

Palabras Clave: África, defaunación, frugívoros, grandes herbívoros, reintegración de fauna silvestre, restauración ecológica, santuario de vida silvestre

\section{Introduction}

Large mammals are particularly vulnerable to anthropogenic pressures such as deforestation, habitat fragmentation, hunting, and poaching (Giacomini \& Galetti 2013; Vidal et al. 2013). The Anthropocene defaunation (Ceballos 2002; Ceballos et al. 2015) can disrupt natural ecosystem functions, such as pollination (Regan et al. 2015) and seed dispersal (Vidal et al. 2013), such that, for example, plant recruitment and forest regeneration are negatively affected (Christian 2001; Traveset et al. 2014).

Seed dispersal, in particular is a key ecosystem function that allows plants to avoid high mortality rates near the parent plant, occupy newly available niches, and expand their range (Howe \& Smallwood 1982; Traveset et al. 2014). Up to $80 \%$ of tree species depend on animal dispersers in tropical forests (Howe \& Smallwood 1982). The effectiveness of the seed-dispersal service depends on the quantity of seeds moved and the quality of the treatment conferred on dispersed seeds, including the effect of gut passage on seed germination, dispersal distance, and quality of the deposition site for germination and recruitment (Moore 2001; Schupp et al. 2010).

Large frugivores have large mouth gape width and frequently high mobility; consequently, they feed on fruits with a wide range of sizes and provide a critical service for long-distance seed dispersal (Fragoso et al. 2003; Holbrook \& Loiselle 2009). Among ecosystem functions, seed dispersal is particularly poorly studied on the African continent, where many of the key animal dispersers are highly threatened, including elephants, primates, fruit bats, and large birds (Vanthomme et al. 2010; CamposArceiz \& Blake 2011; Schleuning et al. 2011). Population declines and extirpations of these species raise serious concerns about the regeneration of African forests in the face of the ongoing African defaunation (Kitamura et al. 2002; Guimarães et al. 2008; Canale et al. 2012), even if their real impact is hidden by seemingly intact forests (Redford 1992; Wilkie et al. 2011). Given the advanced stage of defaunation of many African communities, an equally relevant question is whether conservation measures aimed at recovering animal populations can effectively reinstate seed-dispersal services. However, the functional effectiveness of refaunation remains poorly understood (Brodie \& Aslan 2012; Galetti \& Dirzo 2013) due to the paucity of large-scale refaunation programs and to the methodological challenges associated with monitoring their effectiveness (Montoya et al. 2012; Pringle 2012).

The ongoing refaunation program of the Gorongosa National Park (GNP) in Mozambique (Fig. 1) offers such unique opportunity. The GNP was once famous for holding a staggering density of wildlife until a long war from 1977 to 1992 drove most large animals to the verge of extirpation (Tinley 1977; Pringle 2012; Stalmans 2012). Such severe declines likely lead to a degradation of the services provided by the remaining animals; however, these effects have not been quantified in GNP as they have been elsewhere (McConkey \& Drake 2006). Legal protection and an ambitious restauration project have restored many of the most charismatic species to the GNP, chiefly due to the construction in 2006 of a $62-\mathrm{km}^{2}$ fenced wildlife sanctuary designed to protect relocated wildlife, chiefly buffalo (Syncerus caffer) and wildebeests (Connochaetes taurinus; Supporting Information), until the populations were large enough to be released into the wild (Anderson et al. 2006; Stalmans et al. 2014). From 2006 to 2014, the sanctuary excluded predators and provided more protection against poaching than other parts of the park. These conditions facilitated the reintroduction of some large grazers, but more importantly smaller grazers (e.g., oribi [Ourebia ourebi], impala [Aepyceros melampus], and bushbuck [Tragelaphus sylvaticus]) were given the chance to recover their populations naturally (Stalmans 2006). Within a few years, animal density and diversity inside the sanctuary increased rapidly. Some species' populations more than doubled (e.g., wildebeest and waterbuck [Kobus ellipsiprymnus]; Stalmans 2012).

This unique situation provided the opportunity for a natural experimental on the effect of refaunation on the structure and functioning of seed-dispersal networks. Specifically, we sought to determine whether recovery of the animal populations effectively restored seed-dispersal services. To explore this question, we applied a network approach, which has proved highly valuable in studies of 


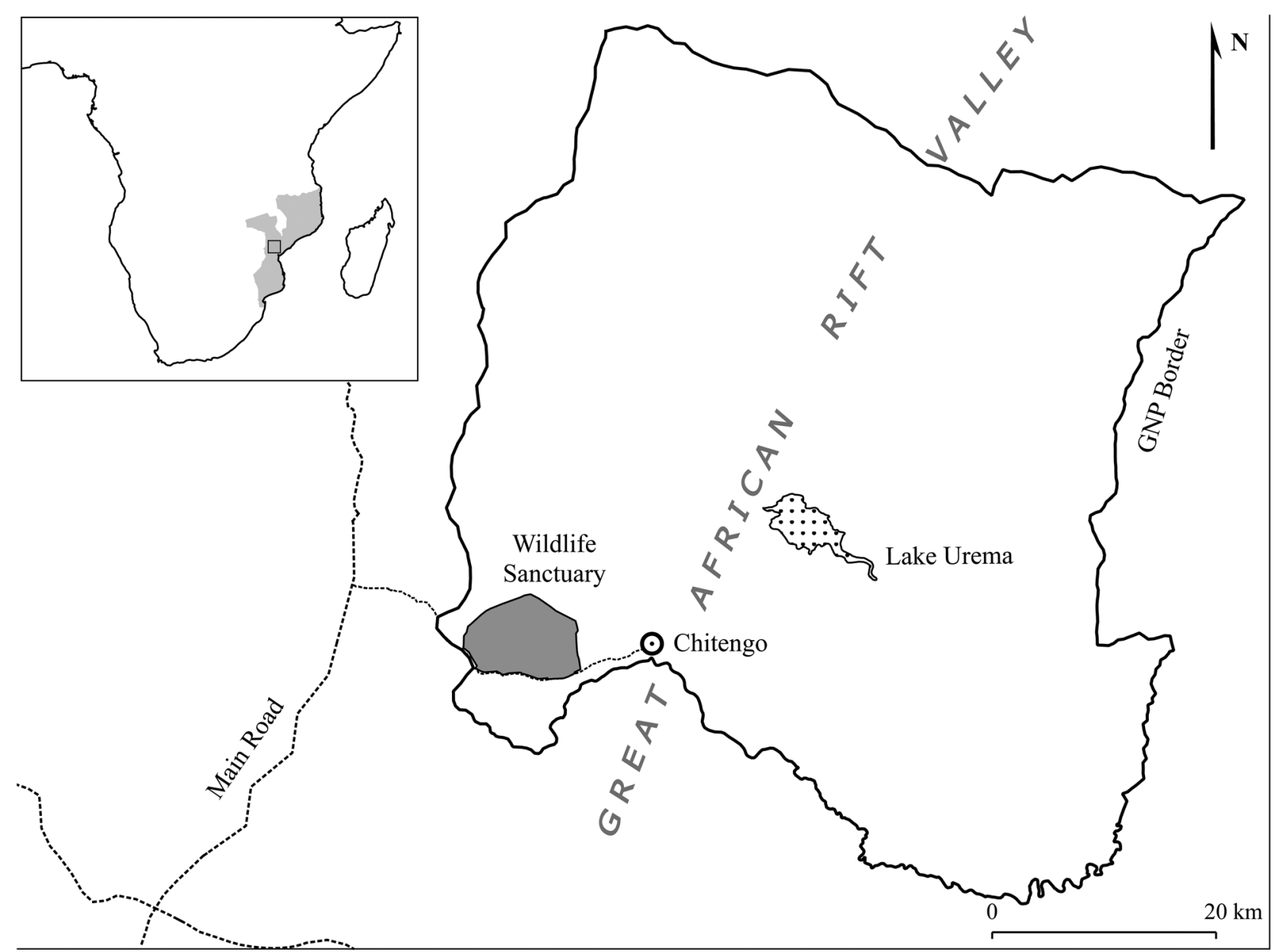

Figure 1. Location of the Gorongosa National Park (GNP) in Mozambique, Africa (inset), and its 62-km ${ }^{2}$ fenced wildlife sanctuary.

seed dispersal at the community level (e.g., Schleuning et al. 2012; Heleno et al. 2013a; Ribeiro da Silva et al. 2015) and particularly in evaluating the effectiveness of ecological restoration (Heleno et al. 2010; KaiserBunbury \& Blüthgen 2015). We hypothesized that the greater the animal diversity and abundance the greater the diversity and abundance of seeds dispersed.

\section{Methods}

\section{Field Site}

Gorongosa National Park, a protected area with 4,067 $\mathrm{km}^{2}$, is in Mozambique at the southern end of the Great Rift Valley (Fig. 1). From August 2006 to September 2014, a $62-\mathrm{km}^{2}$ fenced wildlife sanctuary (hereafter sanctuary) was deployed inside GNP. The fenced areas was approximately $2 \%$ of the total area of the park and was erected as part of a large restoration program to protect recovering wildlife, which included reintroduced species and species that were not completely extirpated, from predators and poachers (Anderson et al. 2006) (Fig. 1). The sanctuary landscape matched that of the natural landscapes of GNP, encompassed several forest types, and formed a mosaic of the primary vegetation types of Brachystegia spp., Combretum spp., and Acacia spp. and a small proportion of alluvial and riverine grasslands (Stalmans 2006). The climate is characterized by wet and hot summers and cool and dry winters (Tinley 1977). Extensive floods during the wet season are a key driver of most ecosystem dynamics, and the dry season is often marked by large wild fires of human and natural origins (Tinley 1977; Daskin et al. 2016).

\section{Sampling}

We collected animal feces (scats) during the dry season of 2014 (June-August) along $5 \mathrm{~km} \times 5 \mathrm{~m}$ transects at least $1 \mathrm{~km}$ apart. We surveyed 5 transects inside and 5 transects outside the sanctuary fence (50 km total). The mean distance between transects inside and outside the sanctuary was $10.5 \mathrm{~km}$, which corresponded to approximately onetenth of the park area. We surveyed in the same type 
of plant community inside and outside the sanctuary. All feces detected along a transect by 2 observers were collected and placed in a numbered plastic bag. The animal species that produced the scat was determined by direct observation or based on experience of the local GNP rangers or field guides (Cillie 2010; Murray 2011). A scat was the feces produced by 1 individual in a single defecation event, regardless of the number of droppings (Galetti et al. 2001; Chame 2003). We collected only fresh and intact scats to avoid contamination by seed rain.

Whole seeds (i.e., undamaged seeds with no signs of predation) were extracted from scats for identification by comparison with a reference collection of seeds. When visual identification was not possible, the seeds were identified by comparing DNA barcoding sequences with sequences in online databases (Supporting Information). We estimated sampling completeness as the proportion of interactions detected inside and outside the sanctuary relative to the total number of interactions estimated by the Chao 2 nonparametric estimator of asymptotic richness (Costa et al. 2016).

\section{Network Construction and Analyses}

Interactions between a seed and a mammal disperser were compiled into quantitative interaction matrices that were visualized and analyzed using the package bipartite (Dormann et al. 2008, 2009; Dormann 2011) for R (R Core Team 2015). For comparison purposes, the seeds retrieved from elephant dung from outside the sanctuary were excluded from analyses because elephants have large home ranges and thus were excluded from the sanctuary before fencing. We quantified seed dispersal based on the frequency of occurrence of seeds in a scat (i.e., the proportion of samples containing one or more seeds of each species) rather than the overall number of seeds found (Vázquez et al. 2005; Heleno et al. 2011). Frequency of occurrence is considered a more realistic measure of the potential recruitment probability because the mortality of many small seeds dispersed in the same scat is likely density dependent due to high levels of competition during recruitment (Howe 1986; Harms et al. 2000). Differences in sample size (number of scats), species richness of animal dispersers and plants dispersed, and links of animal and plant species between the inside and outside of the sanctuary were determined with $G$ tests.

To compare the structure of seed-dispersal networks inside and outside the sanctuary, we calculated 5 network-level descriptors (Dormann et al. 2009; Dormann \& Strauss 2014): weighted connectance (proportion of realized links within the network); animal niche overlap; network specialization $(\mathrm{H} 2$ ', selectivity of interaction partners at the network level); weighted network nestedness (WNODF, extent to which a network conforms to a nested pattern); and quantitative modularity $(M)$. We also calculated 2 species-level descriptors: animal specialization $\left(d^{\prime}\right)$ and level of animal linkage (i.e., the number of plants species dispersed by each animal species) (a complete description of these parameters is in Supporting Information). We used a $z$-score test to determine the significance of network-level descriptors relative to 1000 networks generated by the null model r2dtable (Patefield 2013; Dormann \& Strauss 2014). The results are presented as the percentage of the observed value relative to the mean value obtained for randomly generated networks.

We used linear mixed models (LMM) to test for differences in $d^{\prime}$ 'inside and outside the sanctuary and included species as a random factor. We also used an LMM to test for differences in animal linkage level inside and outside the sanctuary and entered species as a random factor. We added animal abundance as a fixed factor to the model because linkage level is likely affected by species abundance (McConkey \& Drake 2006) and used the number of scats as a proxy for animal abundance. We used the Akaike information criterion (to select the model with the best fit). Analyses were conducted using package lme 4 (Bates et al. 2014) in R (R Core Team 2015).

\section{Results}

Overall, 475 scats produced by 24 animal species were collected, most of them inside the wildlife sanctuary (inside $=268$, outside $=207, G_{1}=7.60, p=0.006$; Supporting Information). Similarly, a higher number of scats containing seeds (i.e., interactions) (inside $=132$, outside $=93, G_{1}=0.011, p=0.006$ ) were found inside the sanctuary. Forty-seven percent of the scats (total 225) contained at least 1 seed (total 4537 seeds, inside $=$ 2413 , outside $\left.=2124, G_{1}=18.30, p<0.001\right)$ of the 43 plant species found in the scats of 17 species (Fig. 2). Primates (baboon [Papio ursinus] and vervet monkey [Cercopithecus pygerythrus]) were the main dispersers both inside and outside the sanctuary ( $42 \%$ and $21 \%$ of the interactions, respectively) followed by the African civet (Civettictis civetta) (12\% of the interactions in both areas). The majority of the seeds corresponded to native fleshy-fruited trees. Seven out of the 33 plant species identified were introduced (Fig. 2), but none of these were invasive. Four native plant species were represented in up to $55 \%$ of all interactions: Ziziphus mucronata (21\%), Tamarindus indica (16\%), Grewia inequilatera (11\%), and Dicrostachys cinerea (8\%).

Species-accumulation curves showed that the level of sampling completeness was very similar inside and outside the sanctuary: $87 \%$ and $78 \%$ of the animal species and $60 \%$ and $59 \%$ of the plant species were detected, respectively. The seed-dispersal network was larger inside the sanctuary (17 animal species dispersed the seeds of 33 plant species) than outside (11 animals dispersed 

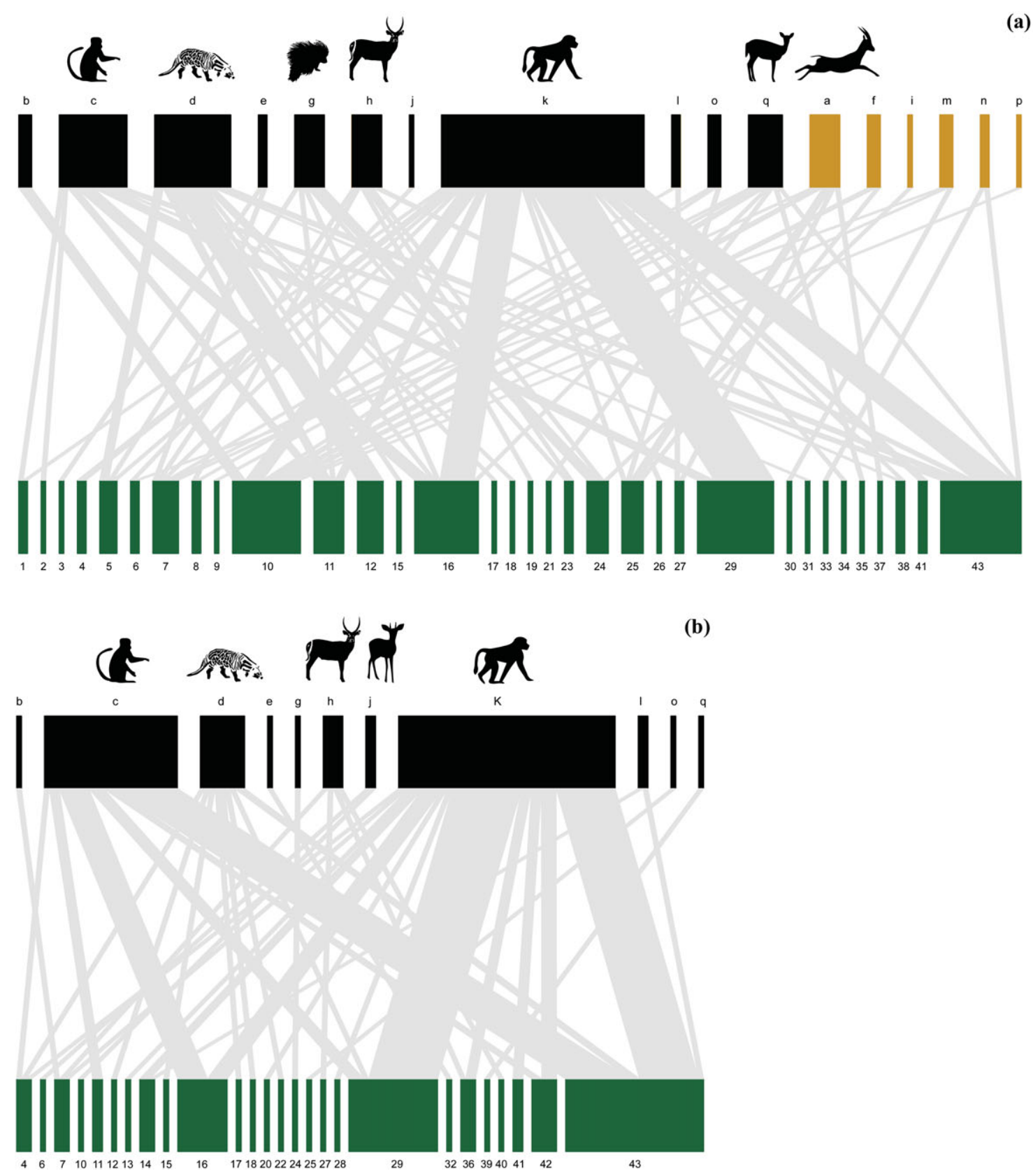

Figure 2. Quantitative seed-dispersal networks (a) inside the wildlife sanctuary and (b) outside the sanctuary. Both networks were sampled with the same level of effort and are represented on the same scale (numbered boxes, plant species dispersed; lettered boxes, animal dispersers; boxes $a, f, i, m, n$, p, dispersers exclusive to the wildlife sanctuary; links, interactions between dispersers and plant species; link width, proportional to the frequency of occurrence of intact seeds on animal scats; dispersers: $a$, impala; $b$, duiker; $c$, vervet monkey; $d$, civet; $e$, genet; $f$, sable antelope; g, porcupine; $h$, waterbuck; $i$, boney badger; $j$, oribi; $k$, baboon; $l$, warthog; $m$, reedbuck; $n$, eland; o, nyala; p, kudu; q, busbbuck; plant species: 1, Acacia nilotica [N, native]; 2, Amaranthus dubius [I, introduced]; 3 , Bobgunnia madagascariensis [I]; 4, Bridelia mollis [N]; 5, Cassia abreviatta [N]; 6, Catunaregam sp, [N]; 7, Centaurea praecox $[N]$; 8 , Cucumis africanus $[N]$; 9, Cyperus $s p$. [N]; 10, Dicrostachys cinerea [N]; 11, Diospyros mespiliformis [N]; 12, Diospyros senensis [N]; 13, Diospyros squarrosa [N]; 14, Eriochloa meyeriana [N]; 15, Grewia caffra [N]; 16, Grewia inequilatera $[N] ; 17$, Grewia microcarpa [N]; 18, Grewia $s p$. [N]; 19, Indigofera $s p$. [N]; 20, Mimusops obtusifolia [N]; 21, Opuntia sp. [I]; 22, Panicum coloratum [N]; 23, Pistia stratiotes [I]; 24, Salicaceae [N]; 25, Solanum incanum [I]; 26, Solanum sp. [I]; 27, Sporobolus panicoides [N]; 28, Tabernaemontana elegans [N]; 29, Tamarindus indica [N]; 30-40 unidentified seed species; 41, Xanthocercis zambesiaca [N]; 42, Ziziphus mauritiana [I]; 43, Ziziphus mucronata [N]). 
the seeds of 26 plants) (Fig. 2). Although the differences between species richness of plants and animals were not significant $\left(G_{1}<0.90 ; p>0.34\right)$, there were more unique links inside than outside the sanctuary (inside $=97$; out side $=69 ; G_{1}=0.52 ; p<0.036$ ). Six animal species dispersed seeds exclusively inside the sanctuary (Fig. 2a \& Supporting Information).

The overlap of plant species dispersed was greater inside the sanctuary than outside the sanctuary, and network specialization was greater outside than inside. Connectance nestedness, and modularity did not differ significantly between the 2 networks (Table 1). Both networks were significantly antinested (i.e., significantly less nested than randomly assembled networks) (Table 1). Animal specialization was lower inside the sanctuary than outside the sanctuary (inside $=0.46$, outside $=0.69$; LMM, $p=0.018$ ) (Supporting Information). Similarly, animal-linkage level was greater inside than outside the sanctuary (inside $=4.2$, outside $=3.5 ;$ LMM, $p<0.018$ ) (Supporting Information), which was explained by the number of scats (a proxy of disperser abundance; LMM, $p$ $<0.001$ ) (Supporting Information) and by the 6 disperser species that occurred exclusively inside the sanctuary (Fig. 2). Most species (17 out of $24,71 \%$ ) produced more scats inside than outside the sanctuary, and of these only 1 (4\%) dispersed more plants outside the sanctuary (Fig. 3 \& Supporting Information).

\section{Discussion}

There is compelling evidence that defaunation negatively affects the ecosystem service of seed dispersal (Guimarães et al. 2008; Terborgh et al. 2008; Ripple et al. 2015). However, whether conservation strategies targeting the recovery of animal populations (e.g., refaunation) can reinstate the seed-dispersal function is still unknown. Our study represents the first attempt to quantify the community-level effects of large-animal refaunation on seed dispersal. Overall, we found a higher richness of dispersers inside the refaunated area (17 vs. 11), which translates into a more complete dispersal service, as revealed by the greater number of scats found (268 vs. 207) with more seeds (2413 vs. 2124) of more plant species (33 vs. 26) inside than outside the sanctuary. The seed-dispersal network in the sanctuary was larger (more diverse) and more complex (more links) than outside the sanctuary. This greater complexity was not due to the presence of new disperser species; rather, it was due to the greater abundance of dispersers inside the sanctuary.

It was not possible to set up replicated and independent experimental and control plots. This limitation was overcome by comparing the direction and magnitude of the variation of key network descriptors between the empirical seed-dispersal networks and the virtual networks

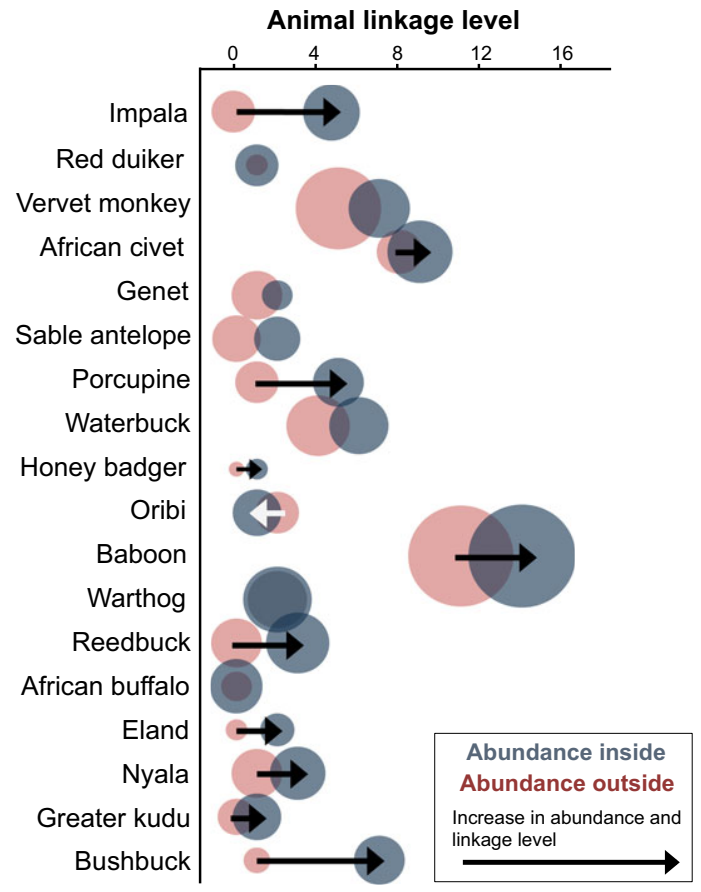

Figure 3. Animal linkage level (i.e., number of plant species dispersed by each animal species inside and outside the sanctuary for each disperser. The size of the circles is proportional to the number of scats sampled, a proxy of animal abundance. The arrows show the direction of the increase in abundance and linkage level.

assembled under null model expectation (Dormann et al. 2008, 2009; Heleno et al. 2013b; Ribeiro da Silva et al. 2015). The removal of the sanctuary fence in September 2014 limited the duration of the study to 3 months; thus, our samples represent a specific period of fruit availability. For that reason, we cannot extrapolate our results to the rest of the year or to other seasons. Nevertheless, estimated sampling completeness was very similar inside and outside the sanctuary, indicating that although not all dispersal interactions were detected, which is seldom the case in community-level studies (Colwell \& Coddington 1994), the results are directly comparable. Ideally, viability or germination tests should be performed to confirm that intact seeds are viable (Schupp et al. 2010); however, visual inspection of seeds provides a good proxy of seed viability (Sawma \& Mohler 2002; Konarzewski et al. 2012). Moreover, most of the disperser species we identified are legitimate seed dispersers (e.g., chacma baboon [Slater \& du Toit 2002]; vervet monkey [Foord et al. 1994]; African civet and duiker [Cephalophus natalensis] [Beaune et al. 2013]; impala and kudu [Tragelaphus strepsiceros] [Miller 1996]; eland [Taurotragus oryx]; and wildebeest [Shiponeni \& Milton 2006]).

The animals dispersed more plant species and more seeds inside the sanctuary than outside, which 
Table 1. Network-level descriptors calculated for inside and outside the sanctuary quantitative seed-dispersal networks.

\begin{tabular}{|c|c|c|c|c|}
\hline Descriptor & observed $\left(\% M O^{a}\right)$ & $p^{b}$ & observed $(\% \mathrm{MO})^{a}$ & $p^{b}$ \\
\hline Niche overlap & $0.16(64.0)$ & 0.055 & $0.07(23.6)$ & $<0.001$ \\
\hline Network specialization (H2') & $0.38(203.2)$ & $<0.001$ & $0.44(239.1)$ & 0.000 \\
\hline Nestesdess (WNODF) & $10.65(58.0)$ & 0.004 & $10.61(44.10)$ & 0.000 \\
\hline
\end{tabular}

contributed to the higher level of overlap of dispersed plant species inside than outside the sanctuary and reduced the specialization of the dispersers and of the entire network. This indicates the sanctuary had a higher functional redundancy of dispersers. Although we did not follow seed fate, as seeds become dispersed by a greater diversity of dispersers, the seed shadow, the diversity of deposition sites, and the heterogeneity of the treatments conferred to the dispersed seeds are all likely to increase thus increasing the probability of effective recruitment (Moore 2001). This diversification of the potential seeddispersal pathways is then critical for the regeneration of plant communities (Moore 2001; Traveset et al. 2001). Many of the dispersers we identified have large gut retention times and are highly mobile; thus, they can potentially move seeds large distances (Pendje 1994; Peres \& van Roosmalen 2002). For example, baboon (Papio spp.) can have home ranges of up to $40 \mathrm{~km}^{2}$ (Harding 1976) and civets have been recorded to disperse seeds over $100 \mathrm{~m}$ (Pendje 1994). Many of these animals tended to deposit seeds in vegetation gaps, where seedlings would have a higher probability of recruiting. For instance, during scat collection we observed seeds germinating in latrines used by civets relatively often.

Ecological redundancy is the basis for ecosystem resilience to disturbance; the presence of multiple species in the same functional group (e.g., seed dispersers) provides a functional backup when the abundance of one or more of these decreases (Walker 1995; García et al. 2013). We did not have the data needed to evaluate the qualitative component of seed dispersal and subsequently to predict possible secondary extinctions or seed-dispersal failure due to loss of some disperser species (Schupp et al. 2010; Bueno et al. 2013). The greater diversity of dispersers inside than outside the sanctuary was not explained by the six animal species found only inside the sanctuary because these species dispersed only a few plants ( $<4$ species). Instead, the higher number of plants dispersed inside the sanctuary was explained by higher densities the populations of common dispersers reached inside the sanctuary (Fig. 3). Because $80 \%$ of the species occurred both inside and outside the sanctuary, we found that it was their abundance, not their traits, that made the difference in relation to their capacity to disperse seeds. This idea is consistent with the positive correlation between the animal linkage level and the number of scats analyzed (a proxy of animal abundance) (Fig. 3) and with the results of Vázquez et al. (2007). These results highlight the importance of the dispersers' population density for the quantitative component of seed-dispersal effectiveness (Fig. 3). A similar relationship has been found for flying foxes (Pteropus tonganus) in Tonga (McConkey \& Drake 2006).

Some studies show that defaunation can increase the recruitment of some plant species due to reduced herbivory of seedlings (Dirzo \& Miranda 1991; Wright et al. 2007). Increased recruitment may affect the dynamics of ecosystems, including in GNP (Vanthomme et al. 2010; Galetti et al. 2013; Daskin et al. 2016). Conversely, high densities of herbivores can also selectively affect seed and seedling predation and grazing and trampling rates and hence alter plant species richness (Cumming \& Cumming 2003; Hobbs 2006). However, the density of large herbivores inside the sanctuary never reached the very high densities observed in pre-war times in the GNP (Supporting Information; Tinley 1977). African savannas can support an exceptional faunal diversity and herbivore density and biomass, mostly due to their high productivity and heterogeneity (Du Toit \& Cumming 1999).

Mutualistic networks tend to be highly structured, where species are part of interacting modules (i.e., groups of tightly interacting species) and interactions follow a nested pattern in which the set of links for each species is not random but nested within the set of links of more generalist species (Bascompte et al. 2003; Rezende et al. 2007; Fortuna et al. 2010). In our study, both seed-dispersal networks (inside and outside the sanctuary) were significantly modular, but both were significantly less nested than expected by chance. Such a modular and antinested structure suggests that dispersers are not all equivalent, dispersing seeds according to their abundance, as in a fully nested pattern (Blüthgen 2010; Fortuna et al. 2010); But are in different modules servicing different kinds of plants (Nogales et al. 2016). 
Gorongosa National Park is a highly dynamic system, where the establishment of dominant vegetation is constantly reset by megafauna trampling and herbivory, large wildfires, and recurrent floods (Tinley 1977; Daskin et al. 2016). Under such conditions, seed dispersal is particularly important because it represents the only mechanism by which plants can reclaim habitat and persist regionally by occupying a highly dynamic set of mosaics (Hanski 1997; Traveset et al. 2014). A diverse assemblage of animal dispersers is critical to maintain long-term vegetation dynamics and forest regeneration (Terborgh 2013; Traveset et al. 2014). In this sense, defaunation represents a major conservation threat not only for animals but also for plants because it alters important ecosystem services over the long-term (Terborgh et al. 2008; Beaune et al. 2013; Bello et al. 2015). Therefore, the success of ecological restoration is contingent on the reinstatement of the ecological processes that sustain functional communities and not just on the recovery of flagship species (Palmer et al. 2006; Heleno et al. 2010). Based on our results, we believe the refaunation of GNP has the potential to reinstate the seed-dispersal function provided by large animals to the area's diverse plant community.

\section{Acknowledgments}

This work was supported by FEDER funds from the Programa Operacional Factores de Competitividade COMPETE and by national funds from the Portuguese Foundation for Science and Technology - FCT through the research project PTDC/BIA-BIC/4019/2012. M.C., R.H.H., and S.R.E. were also supported by FCT (grants SFRH/BD/96050/2013, IF/00441/2013, and IF/00462/2013, respectively). We thank the Greg Carr Foundation - Gorongosa Restoration Project, the staff of GNP, and the Edward O. Wilson Biodiversity Laboratory for logistical support of fieldwork. We also thank H. Almeida for laboratory assistance, H. Freitas and V. Ferrero for their input in the early stages of this project, and J. Valverde for sharing consensus-modularity scrip.

\section{Supporting Information}

The abundance of large animals in the GNP over the last decades (Appendix S1), the protocol used for DNA barcoding of seeds (Appendix S2), the description of network parameters (Appendix S3), the number of scats and plant species dispersed by each disperser species inside and outside the sanctuary (Appendix S4), and the output of the linear mixed models (Appendix S5) are available online. The authors are solely responsible for the content and functionality of these materials. Queries (other than absence of the material) should be directed to the corresponding author.

\section{Literature Cited}

Anderson JL, Beilfuss RD, Pereira CL, Zolho R. 2006. Proposed strategy to reintroduce and supplement wildlife populations in Gorongosa National Park, Moçambique.

Bascompte J, Jordano P, Melián CJ, Olesen JM. 2003. The nested assembly of plant-animal mutualistic networks. Proceedings of the National Academy of Sciences of the United States of America 100:9383-9387.

Bates D, Mächler M, Bolker B, Walker S. 2014. Fitting linear mixedeffects models using lme4. Preprint. Available from arXiv preprint arXiv:1406.5823 (accessed September 2016).

Beaune D, Bretagnolle F, Bollache L, Hohmann G, Surbeck M, Fruth B. 2013. Seed dispersal strategies and the threat of defaunation in a Congo forest. Biodiversity and Conservation 22:225-238.

Bello C, Galetti M, Pizo MA, Magnago LFS, Rocha MF, Lima RAF, Peres CA, Ovaskainen O, Jordano P. 2015. Defaunation affects carbon storage in tropical forests. Science Advances 1:1-11.

Blüthgen N. 2010. Why network analysis is often disconnected from community ecology: a critique and an ecologist's guide. Basic and Applied Ecology 11:185-195

Brodie JF, Aslan CE. 2012. Halting regime shifts in floristically intact tropical forests deprived of their frugivores. Restoration Ecology 20:153-157.

Bueno RS, Guevara R, Ribeiro MC, Culot L, Bufalo FS, Galetti M. 2013. Functional redundancy and complementarities of seed dispersal by the last neotropical megafrugivores. PLoS ONE 8(e56252) DOI: 10.1371/journal.pone.0056252.

Campos-Arceiz A, Blake S. 2011. Megagardeners of the forest - the role of elephants in seed dispersal. Acta Oecologica 37:542-553

Canale GR, Peres CA, Guidorizzi CE, Gatto CAF, Kierulff MCM. 2012. Pervasive defaunation of forest remnants in a tropical biodiversity hotspot. PLoS ONE 7(e41671) DOI: 10.1371/journal.pone.0041671.

Ceballos G. 2002. Mammal population losses and the extinction crisis. Science 296:904-907.

Ceballos G, Ehrlich PR, Barnosky AD, García A, Pringle RM, Palmer TM. 2015. Accelerated modern human - induced species losses: entering the sixth mass extinction. Sciences Advances 1:1-5.

Chame M. 2003. Terrestrial mammal feces: a morphometric summary and description. Memorias do Instituto Oswaldo Cruz 98:7194.

Christian CE. 2001. Consequences of a biological invasion reveal the importance of mutualism for plant communities. Nature 413:635639

Cillie B. 2010. Pocket guide to mammals of Southern Africa. 5th edition Sunbird Publishers, Cape Town.

Colwell RK, Coddington JA. 1994. Estimating terrestrial biodiversity through extrapolation. Philosophical transactions of the Royal Society of London. Series B, Biological Sciences 345:101118

Costa JM, da Silva LP, Ramos JA, Heleno RH. 2016. Sampling completeness in seed dispersal networks: when enough is enough. Basic and Applied Ecology 17:155-164.

Cumming DHM, Cumming GS. 2003. Ungulate community structure and ecological processes: body size, hoof area and trampling in African savannas. Oecologia 134:560-568.

Daskin JH, Stalmans M, Pringle RM. 2016. Ecological legacies of civil war: 35 -year increase in savanna tree cover following wholesale large-mammal declines. Journal of Ecology 104:79-89.

Dirzo R, Miranda A. 1991. Altered patterns of herbivory and diversity in the forest understory: a case study of the possible consequences of contemporary defaunation. Pages 273-287 in Price WWBPW, Lewinsohn TM, Fernandes GW, editors. Plant-animal interaction: evolutionary ecology in tropical and temperate regions. John Wiley and Sons, New York.

Dormann CF. 2011. How to be a specialist? Quantifying specialisation in pollination networks. Network Biology 1:1-20. 
Dormann CF, Fründ J, Bluthgen N, Gruber B. 2009. Indices, graphs and null models: analysing bipartite ecological networks. The Open Ecology Journal 2:7-24.

Dormann CF, Strauss R. 2014. A method for detecting modules in quantitative bipartite networks. Methods in Ecology and Evolution 5:90-98.

Dormann C, Gruber B, Fründ J. 2008. Introducing the bipartite package: analysing ecological networks. R News 8:8-11.

Du Toit JT, Cumming DHM. 1999. Functional significance of ungulate diversity in African savannas and the ecological implications of the spread of pastoralism. Biodiversity and Conservation 8:16431661.

Foord SH, Van Aarde RJ, Ferreira SM. 1994. Seed dispersal by vervet monkeys in rehabilitating coastal dune forests at Richards Bay. South African Journal of Wildlife Research 24:56-59.

Fortuna MA, Stouffer DB, Olesen JM, Jordano P, Mouillot D, Krasnov BR, Poulin R, Bascompte J. 2010. Nestedness versus modularity in ecological networks: Two sides of the same coin? Journal of Animal Ecology 79:811-817.

Fragoso JMV, Silvius KM, Correa JA. 2003. Long-distance seed dispersal by tapirs increases seed survival and aggregates tropical trees. Ecology 84:1998-2006.

Galetti M, et al. 2013. Functional extinction of birds drives rapid evolutionary changes in seed size. Science 340:1086-1090.

Galetti M, Dirzo R. 2013. Ecological and evolutionary consequences of living in a defaunated world. Biological Conservation 163:1-6.

Galetti M, Keuroghlian A, Hanada L, Morato MI. 2001. Frugivory and seed dispersal by the lowland tapir. Biotropica 33:723-726.

García D, Martínez D, Herrera JM, Morales JM. 2013. Functional heterogeneity in a plant-frugivore assemblage enhances seed dispersal resilience to habitat loss. Ecography 36:197-208.

Giacomini HC, Galetti M. 2013. An index for defaunation. Biological Conservation 163:33-41.

Guimarães PR, Galetti M, Jordano P. 2008. Seed dispersal anachronisms: rethinking the fruits extinct megafauna ate. PLoS ONE 3 (e1745) DOI: 10.1371/journal.pone.0001745.

Hanski I. 1997. Metapopulation dynamics. Nature 396:41-49.

Harding RSO. 1976. Ranging patterns of a troop of baboons (Papio anubis) in Kenya. International Journal of Primatology 25:143185.

Harms KE, Wright SJ, Calderón O, Hernández A, Herre EA. 2000. Pervasive density-dependent recruitment enhances seedling diversity in a tropical forest. Nature 404:493-495.

Heleno RH, Olesen JM, Nogales M, Vargas P, Traveset A. 2013a. Seed dispersal networks in the Galápagos and the consequences of alien plant invasions. Proceedings of the Royal Society B 280:20122112.

Heleno RH, Ramos JA, Memmott J. 2013b. Integration of exotic seeds into an Azorean seed dispersal network. Biological Invasions 15:1143-1154

Heleno RH, Ross G, Everard AMY, Memmott J, Ramos JA. 2011. The role of avian "seed predators" as seed dispersers. Biological Invasions 153:199-203.

Heleno R, Lacerda I, Ramos JA, Memmott J. 2010. Evaluation of restoration effectiveness: community response to the removal of alien plants. Ecological Applications 20:1191-1203.

Hobbs NT. 2006. Large herbivores as sources of disturbance in ecosystems. Pages 261-288 in Danell K, Bergstrom R, Duncan P, Pastor J, editors. Large herbivore ecology, ecosystem dynamics and conservation. Cambridge University Press, United Kingdom.

Holbrook KM, Loiselle BA. 2009. Dispersal in a Neotropical tree, Virola flexuosa (Myristicaceae): does hunting of large vertebrates limit seed removal? Ecology 90:1449-1455.

Howe HF. 1986. Seed dispersal by fruit-eating birds and mammals. Pages 123-189 in Murray DR, editor. Seed dispersal. Academic Press, Australia.

Howe HF, Smallwood J. 1982. Ecology of seed dispersal. Annual Review of Ecology and Systematics 13:201-228.
Kaiser-Bunbury CN, Blüthgen N. 2015. Integrating network ecology with applied conservation: a synthesis and guide to implementation. AoB Plants 7 DOI: 10.1093/aobpla/plv076.

Kitamura S, Yumoto T, Poonswad P, Chuailua P, Plongmai K, Maruhashi T, Noma N. 2002. Interactions between fleshy fruits and frugivores in a tropical seasonal forest in Thailand. Oecologia 133:559-572.

Konarzewski TK, Murray BR, Godfree RC. 2012. Rapid development of adaptive, climate-driven clinal variation in seed mass in the invasive annual forb Echium plantagineum L. PloS ONE 7 (e49000) DOI:10.1371/journal.pone.0049000.

McConkey KR, Drake DR. 2006. Flying foxes cease to function as seed dispersers long before they become rare. Ecology 87:271-276.

Miller MF. 1996. Dispersal of Acacia seeds by ungulates and ostriches in an African savanna. Journal of Tropical Ecology 12:345-356.

Montoya D, Rogers L, Memmott J. 2012. Emerging perspectives in the restoration of biodiversity-based ecosystem services. Trends in Ecology and Evolution 27:666-672.

Moore PD. 2001. The guts of seed dispersal. Nature 414:406-407.

Murray K. 2011. Scatalog: Quick ID Guide to Southern African Animal DroppingsPenguin Ra. Struik Nature, Cape Town, South Africa.

Nogales M, Heleno R, Rumeu B, González-Castro A, Traveset A, Vargas P, Olesen JM. 2016. Seed-dispersal networks on the Canaries and the Galápagos archipelagos: Interaction modules as biogeographical entities. Global Ecology and Biogeography 25:912-922.

Palmer MA, Falk DA, Zedler JB. 2006. Ecological theory and restoration ecology. Pages 1-10 in Falk DA, Palmer MA, Zedler JB, editors. Foundations of restoration ecology. Island Press, Washington, D.C.

Patefield AWM. 2013. Algorithm AS 159: an efficient method of generating random $\mathrm{R} \times \mathrm{C}$ tables with given row and column totals. Journal of the Royal Statistical Society. Series C (Applied Statistics) 30:91-97.

Pendje G. 1994. Fruit consumption and seed dispersal by the African Civet Civettictis-Civetta in Mayombe, Zaire. Revue D Ecologie-La Terre Et La Vie 2:107-116.

Peres C, van Roosmalen M. 2002. Primate frugivory in two speciesrich Neotropical forests: implications for the demography of largeseeded plants in overhunted areas. Pages 407-423 in Levey DJ, Silva WR, Galetti M, editors. Seed dispersal and frugivory: ecology, evolution, and conservation. CABI Publishing, Wallingfor, Oxon, United Kingdom.

Pringle RM. 2012. How to be manipulative. American Scientist 100:3037.

R Core Team. 2015. R: a language and environment for statistical computing. R Foundation for Statistical Computing, Vienna.

Redford HK. 1992. The empty forest. BioScience 42:412-422.

Regan EC, Santini L, Ingwall-King L, Hoffmann M, Rondinini C, Symes A, Taylor J, Butchart SHM. 2015. Global trends in the status of bird and mammal pollinators. Conservation Letters 8 DOI: 10.1111/conl.12162.

Rezende EL, Lavabre JE, Guimarães PR, Jordano P, Bascompte J. 2007. Non-random coextinctions in phylogenetically structured mutualistic networks. Nature 448:925-928.

Ribeiro da Silva F, Montoya D, Furtado R, Memmott J, Pizo MA, Rodrigues RR. 2015. The restoration of tropical seed dispersal networks. Restoration Ecology DOI: 10.1111/rec.12244.

Ripple WJ, et al. 2015. Collapse of the world's largest herbivores. Science Advances 1:e1400103-e1400103.

Sawma JT, Mohler CL. 2002. Evaluating seed viability by an unimbibed seed crush test in comparison with the tetrazolium test. Weed Technology 16:781-786.

Schleuning M, et al. 2012. Specialization of mutualistic interaction networks decreases toward tropical latitudes. Current Biology 22:1925-1931.

Schleuning M, Blüthgen N, Flörchinger M, Braun J, Martin H, Böhninggaese K. 2011. Specialization and interaction strength in a tropical plant-frugivore network differ among forest strata. Ecology 92:2636. 
Schupp EW, Jordano P, Gómez JM. 2010. Seed dispersal effectiveness revisited: a conceptual review. The New Phytologist 188:333-353.

Shiponeni NN, Milton SJ. 2006. Seed dispersal in the dung of large herbivores: Implications for restoration of Renosterveld shrubland old fields. Biodiversity and Conservation 15:31613175 .

Slater K, du Toit JT. 2002. Seed dispersal by chacma baboons and syntopic ungulates in southern African savannas. South African Journal of Wildlife Research 32:75-79.

Stalmans M. 2006. Vegetation and carrying capacity of the "Sanctuário." International Conservation Services to the Carr Foundation and the Ministry of Tourism, Parque Nacional da Gorongosa, Sofala.

Stalmans M. 2012. Monitoring the recovery of wildlife in the Parque Nacional da Gorongosa through aerial surveys. Parque Nacional da Gorongosa, Sofala

Stalmans M, Peel M, Massad T. 2014. Aerial wildlife count of the Parque Nacional da Gorongosa, Mozambique, October 2014. Parque Nacional da Gorongosa, Sofala.

Terborgh J. 2013. Using Janzen-Connell to predict the consequences of defaunation and other disturbances of tropical forests. Biological Conservation 163:7-12.

Terborgh J, Nuñez-Iturri G, Pitman NC, Valverde FHC, Alvarez P, Swamy V, Pringle EG, Paine CET. 2008. Tree recruitment in an empty forest. Ecology 89:1757-1768.

Tinley KL. 1977. Framework of the Gorongosa ecosystem. University of Pretoria, Pretoria.
Traveset A, Heleno R, Nogales M. 2014. Seeds: the ecology of regeneration in plant communities. Pages 62-93 in Gallagher R, editor. 3rd edition. The ecology of seed dispersal. CABI, Oxon, United Kingdom.

Traveset A, Riera N, Mas RE. 2001. Passage through bird guts causes interspecific differences. Functional Ecology 15:669-675.

Vanthomme H, Bellé B, Forget PM. 2010. Bushmeat hunting alters recruitment of large-seeded plant species in Central Africa. Biotropica 42:672-679.

Vázquez DP, Melián CJ, Williams NM, Blüthgen N, Krasnov B, Poulin R. 2007. Species abundance and asymmetric interaction strength in ecological networks. Oikos 116:1120-1127.

Vázquez DP, Morris WF, Jordano P. 2005. Interaction frequency as a surrogate for the total effect of animal mutualists on plants. Ecology Letters 8:1088-1094.

Vidal MM, Pires MM, Guimarães PR. 2013. Large vertebrates as the missing components of seed-dispersal networks. Biological Conservation 163:42-48.

Walker B. 1995. Conserving biological diversity through ecosystem resilience. Conservation Biology 9:747-752.

Wilkie DS, Bennett EL, Peres CA, Cunningham AA. 2011. The empty forest revisited. Annals of the New York Academy of Sciences 1223:120-128.

Wright SJ, Hernandéz A, Condit R. 2007. The bushmeat harvest alters seedling banks by favoring lianas, large seeds, and seeds dispersed by bats, birds, and wind. Biotropica 39:363-371. 